\title{
The Gastric and Duodenal Eosinophilia in Functional Dyspepsia
}

\author{
Hyun Jin Kim \\ Department of Internal Medicine, Gyeongsang National University Changwon Hospital, Gyeongsang National University College of Medicine, \\ Jinju, Korea
}

\section{Article: Analysis of gastric and duodenal eosinophils in children with abdominal pain related functional gastrointestinal disorders according to Rome III criteria \\ Lee EH, Yang HR, Lee HS \\ (J Neurogastroenterol Motil 2016;22:459-469)}

Functional dyspepsia (FD) is a common functional gastrointestinal (GI) disorder ( 1 in 10 people), and a chronic clinical syndrome associated with postprandial fullness, early satiation, epigastric burning, or epigastric pain. As valid clinical entities postprandial distress syndrome and epigastric pain syndrome are accepted. ${ }^{1}$

The pathogenesis of FD still remains to be established. However, many data suggest that environmental (inflections including Helicobacter pylori and diet), physiologic (acid, gastric accommodation, gastric emptying, and duodenal sensitivity), psychologic (anxiety, depression, and brain pain modulating circuits), and biologic (genes, cytokines, and duodenal eosinophilia) factors may play a role in the pathophysiology of $\mathrm{FD} .^{1}$

The role of eosinophilia in functional dyspepsia is not well established. It was hypothesized that eosinophils secondary to duodenal acid or food allergy accumulates in some patients with $\mathrm{FD}$, and degranulate by the release of injured materials. ${ }^{2}$ Also, eosinophilia in the stomach and duodenum is a secondary response to chronic inflammation by $H$. pylori infection.

In the original article of the Journal of Neurogastroenterology and Motility, Lee $\mathrm{EH}$ et $\mathrm{al}^{3}$ described the relationship between gas- troduodenal eosinophils and pediatric functional GI disorders. Few papers show that the gastric and duodenal eosinophil density was increased in children with functional GI disorders. ${ }^{4,5}$ This article showed similar results in pediatric patients with functional GI disorders, however, the diagnosis was based on the Rome III criteria, and excluded food allergy, asthma, atropic dermatitis, and rhinitis before the diagnosis. H. pylori infection group showed high eosinophils in the stomach and duodenum, but no statistical significance.

In summary, the gastric and duodenal eosinophilia versus the clinical symptoms of pediatric FD are not as yet clearly correlated. The paper by Lee EH et $\mathrm{al}^{3}$ showed the possibility of correlation between eosinophils in the stomach and duodenal biopsy specimens, and the clinically diagnosed using by Rome III criteria. The results provide the pivotal information regarding the low-grade inflammation associated with functional GI disorders.

\section{Financial support: None.}

\section{Conflicts of interest: None.}

Received: June 13, 2016 Revised: None Accepted: June 13, 2016

(a) This is an Open Access article distributed under the terms of the Creative Commons Attribution Non-Commercial License (http://creativecommons. org/licenses/by-nc/4.0) which permits unrestricted non-commercial use, distribution, and reproduction in any medium, provided the original work is properly cited.

${ }^{*}$ Correspondence: Hyun Jin Kim, MD

Department of Internal Medicine, Gyeongsang National University College of Medicine, 72 Gangnam-ro, Jinju 52727, Korea Tel: +82-55-750-8822, Fax: +82-55-750-8285, E-mail: imdrkim@naver.com 


\section{References}

1. Talley NJ. Functional dyspepsia: new insights into pathogenesis and therapy. Korean J Intern Med 2016;31:444-456.

2. Talley NJ, Walker MM, Aro P, et al. Non-ulcer dyspepsia and duodenal eosinophilia: an adult endoscopic population-based case-control study. Clin Gastroenterol Hepatol 2007;5:1175-1183.

3. Lee EH, Yang HR, Lee HS. Analysis of gastric and duodenal eosino- phils in children with abdominal pain related functional gastrointestinal disorders according to Rome III criteria. J Neurogastroenterol Motil 2016;22:459-469.

4. Friesen CA, Neilan NA, Schurman JV, Taylor DL, Kearns GL, AbdelRahman SM. Montelukast in the treatment of duodenal eosinophilia in children with dyspepsia: effect on eosinophil density and activation in relation to pharmacokinetics. BMC Gastroenterol 2009;9:32.

5. Friesen CA, Lin Z, Singh M, et al. Antral inflammatory cells, gastric emptying, and electrogastrography in pediatric functional dyspepsia. Dig Dis Sci 2008;53:2634-2640. 